\title{
Morphometric Characterization of a Watershed through SRTM Data and Geoprocessing Technique
}

\author{
Elias Rodrigues da Cunha, Vitor Matheus Bacani \\ Geoprocessing Laboratory, Federal University of Mato Grosso do Sul, Aquidauana, Brazil \\ Email: eliasrodriguesdacunha@hotmail.com
}

Received 10 February 2016; accepted 23 April 2016; published 26 April 2016

Copyright $(02016$ by authors and Scientific Research Publishing Inc.

This work is licensed under the Creative Commons Attribution International License (CC BY). http://creativecommons.org/licenses/by/4.0/

(c) (i) Open Access

\begin{abstract}
The aim of this study is to characterize the morphometry of a watershed using radar data Shuttle Radar Topographic Mission (SRTM) and GIS techniques. The study is conducted in the watershed of the Indaiá stream, which is located in the southwestern region of the municipality of Aquidauana, MS, Brazil and has an area of $94.6764 \mathrm{~km}^{2}$. A tributary of the Taboco River consequently enters the Pantanal lowlands. Classical morphometric parameters were calculated and specialized through spatial analysis in geographic information systems. The main results of the morphometric characterization were the variables of form factor, drainage density, coefficient of compactness, and maintenance coefficient, as well as the relief parameters found, including the hypsometry, slope, aspect and relief dissection (horizontal and vertical amplitude). The integrated analysis of the variables (morphometric and relief) concludes that the watershed has low susceptibility to flooding but that the morphology of the relief and lithological structure favors the development of erosion processes in the watershed.
\end{abstract}

\section{Keywords}

SRTM DEM, Morphometric Analysis, GIS, Remote Sensing, Pantanal

\section{Introduction}

Morphometric analysis is a set of procedures that characterize the geometric and compositional aspects of environmental systems, serving as indicators of the related form, structural arrangement and interaction between aspects and the network of fluvial channels in a watershed in situations and values that exacerbate hydrological and geomorphological issues [1]-[13]. 
Studies related to fluvial drainage have always played a central role in hydrological studies seeking to understand the occurrence, distribution, and movement of water and its properties. In geomorphological studies, they constitute one of the most active morphogenetic processes in the composition of terrestrial landscapes. According to Reference [7], the work developed by Robert E. Horton serves as the basis for numerous other research [2] [5] [14] [15], which have ranged from the establishment of laws on the development of rivers and their watershed in a quantitative approach to describing their morphometric character.

More recently, researchers have conducted morphometric analyses using remote sensing and geoprocessing techniques to characterize watersheds [16]-[28]. Previously, this type of analysis for computing the potential of obtaining environmental information demanded costly and time-intensive surveys, field surveys, and office space.

Since the Shuttle Radar Topographic Mission (SRTM) data on South America were first made available in mid-2003, there has been a great expectation with respect to the gains in knowledge concerning our territory, which has justified by the general lack of topographic data at appropriate scales.

Within this perspective, the TOPODATA project was developed at the Instituto Nacional de Pesquisas Espaciais (INPE) to build a national database of topographic data by providing a Digital Elevation (DEM) for all national territory and the major associated topographic variables (altitude, slope, aspects, profile curvature of the sides, horizontal curvature design of drainage channels and watersheds and catchment area). This project uses kriging methods to transform the original SRTM DEM with a new and improved $90 \mathrm{~m}$ to $30 \mathrm{~m}$ resolution [29] [30].

The use of DEM through geographic information systems (GIS) has proven to be a powerful tool because it allows methods for analyzing topographic characteristics with quality and operational advantages. The SRTM data associated with geoprocessing techniques are presented as a way to obtain fast, accurate and low-cost calculations for use in morphometric analyses [28] [31]-[38].

The quantitative analysis of morphometric parameters is of immense utility in the development and prioritization of the conservation of soil and water at a watershed level [39]; within this perspective, the use of data obtained through remote sensing associated with GIS has proven to be a powerful tool for watershed analysis and management [26] [27] [40] [41].

However, the morphometric analysis approaches that are guided by geotechnology have focused on the characterization of specific parameters such as fluvial hierarchy, area and perimeter of the basin, compactness, and form [21] [42]-[44] while neglecting important variables such as the analysis of the degree of horizontal $(\mathrm{H})$ and vertical (V) dissection (the introduced authors emphasize that SIG analyzes these articles and have found no $\mathrm{H}$ and $\mathrm{V}$ ). Thus, there is a large gap in the literature that represents the integration of these variables.

In this context, this study aimed to characterize the morphometry of the watershed using both SRTM radar data and geoprocessing techniques.

\section{Study Area Description}

The watershed of the Indaiá stream is located in the southwestern region of Aquidauana municipality in the state

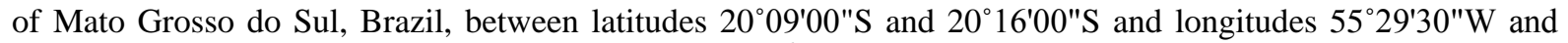
$55^{\circ} 39^{\prime} 00^{\prime \prime} \mathrm{W}$, with an area of approximately $94.6764 \mathrm{~km}^{2}$ (Figure 1). The Indaiá stream is a tributary of the Taboco River before it enters the Pantanal plain. According to Köppen, the climate belongs to the Aw sub-climate zone (tropical humid), with an average annual rainfall of $1.200 \mathrm{~mm}$ and maximum and minimum temperatures of $33^{\circ} \mathrm{C}$ and $19^{\circ} \mathrm{C}$, respectively.

\section{Geology and Geomorphology}

Geologically, the study area comprises the Furnas Formation (Paraná Group), Aquidauna Formation and Alluvial River Current [45]. The sandstones that are predominant in the Furnas Formation are medium to rough, white to light yellow, and quite feldspathic. The highly micaceous sandstone layers are interspersed, often presenting cross-bedding and oligomitic basal conglomerations [46]. For reference [47], the sandstone group in Furnas comprises a sequence of alternating sandstone-shaped seats and plates that are yellowish to gray-white in color.

Reddish-brown brick stands in the sandstones of the Aquidauana Formation [45]. Mineralogically, the grosser levels are predominantly quartz grains, with rare, kaolinized feldspar [47]. For reference [48] red Aquidauana Formation sediments are the result of deposition in the continental environment (river, lake and floodplains). 



Figure 1. Digital model elevation (DEM) and location of the study area.

The alluvial deposits that are currently being deposited on the banks and beds of rivers and streams that drain the area are included. They are characterized by the presence of sand, silt, clay and gravel, usually at a lower level, and are overlapped by the sandy banks of the coarse-grained to fine, silt-containing levels [45].

As described by reference [49] the dominant relief forms are convex hills with slopes ranging from 6\% to $20 \%$, fluvial plain, hillocks and morrotes. The following units of relief and their respective forms (forms) were identified: river plain (APF), relief dissected into convex hills with slopes 6\% - 20\% (Vc), relief dissected into convex hillock tops (Tc), and relief dissected into convex hilltops (Tc).

\section{Materials and Method}

\subsection{Data Used}

The materials used were radar interferometric data from SRTM grid 20_57_ZN (GeoTIFF), mosaic optical images of high-resolution GeoEye satellite (ArcGIS $10^{\circledR}$ online) at a scale of $1: 3.500$ and a $0.63 \mathrm{~m}$ spatial resolution, and the computer applications ArcMap $10^{\circledR}$ and $13^{\circledR}$ Global Mapper.

\subsection{Methodology}

The methodology was based on the procedures described by Reference [1] [2] [5] [6] [50]-[53] according to Figure 2.

By analyzing the radar data SRTM (equidistant from contour extraction $15 \mathrm{~m}$ ) together with the optical image resolution (GeoEye, spatial resolution of $0.63 \mathrm{~m}$ ) that was extracted from ArcGIS 10 online, the basin and subbasins were delimited, and the drainage network was extracted. The parameters of the basin, such as area, perimeter and length (main river, all channels and length of the basin), were generated automatically from the geometry tool, and other parameters were evaluated according to the equations described in Table 1. 


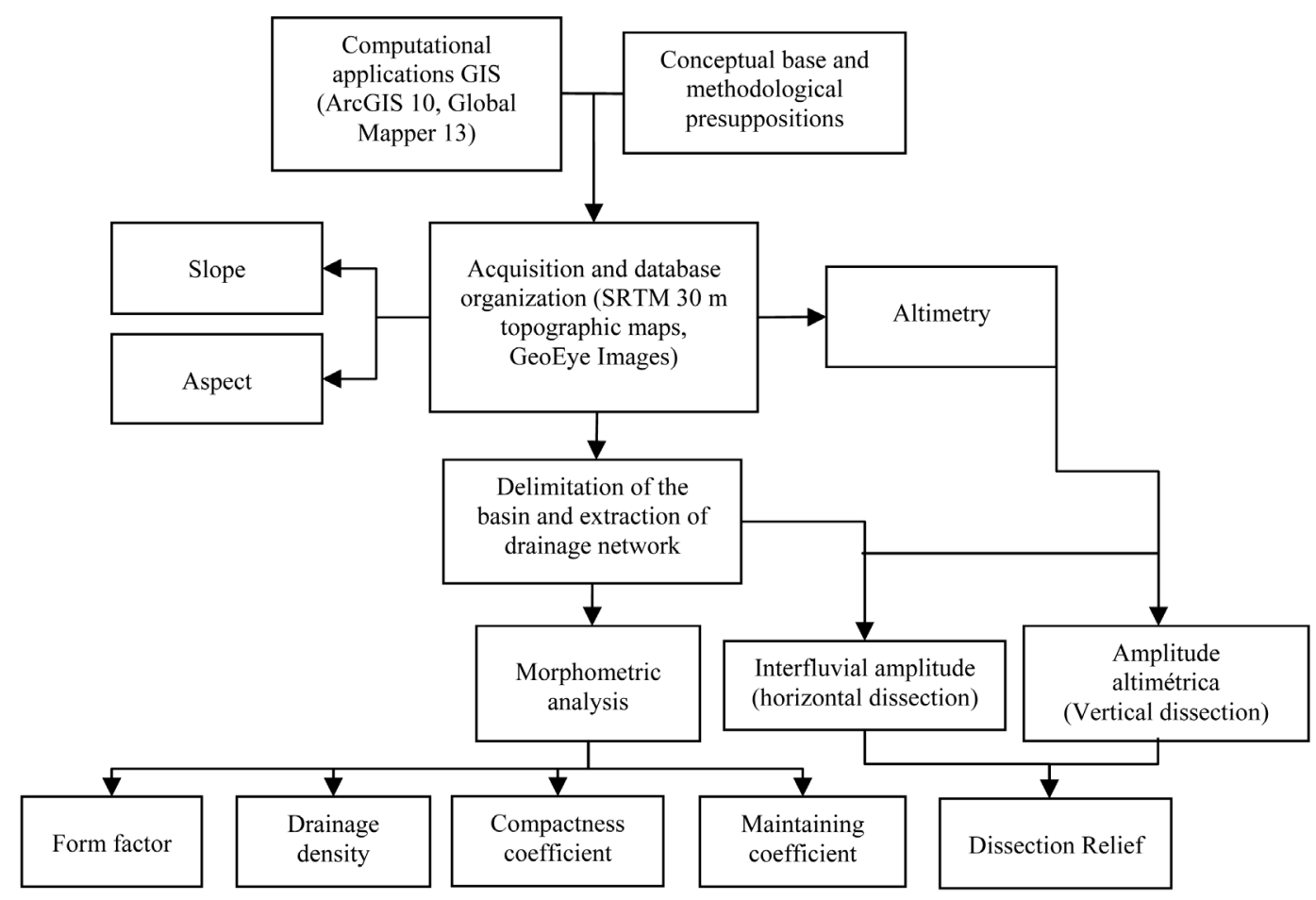

Figure 2. Methodological flowchart.

The numerical modeling of terrain was based on SRTM radar data, with the original resolution of $90 \mathrm{~m}$ refined by kriging to $30 \mathrm{~m}$ by reference [54]. A Regular Rectangular Grid Model (RRMG) was generated in accordance with previously described procedures [55]. The model was extracted by one-dimensional model relief. The hypsometric maps, clinography, aspect and interfluvial dimension were reproduced in the ArcGIS 10 environment. The steps taken were as follows: Arctoolbox > Spatial Analyst Tool > Surface.

\section{Results and Discussion}

\section{Morphometric Analysis}

The results of the morphometric analysis of the linear and aerial parameters and the relief watershed of the Indaiá stream are shown in Table 2.

Drainage area is one of the most important characteristics in hydrology. It reflects the volume of water that can be generated by rain water [27]. The Indaiá stream watershed has a drainage area of $94.6764 \mathrm{~km}^{2}$, its perimeter is $49.0430 \mathrm{~km}^{2}$, and it can be divided into seven sub-basins (Figure 3(a)). The development of the drainage system can be influenced in its morphogenetic activity by nature, geological structure, tectogenetic activities (endogenous) and morphoclimatic mechanisms (exogenous) [7] [38] [56].

The standard of the dendritic drainage basin is structured on the Paraná sedimentary basin characterized by outcrops of sandstones of the Furnas Formation and Aquidauana [45]. According to reference [7], this type of pattern is directly related to the uniform resistance of rocks and sedimentary structures.

The determination of order and the fluvial hierarchy is the first and most important step in the morphometric characterization of basin [39]. It is based on the criteria of reference [2] for determining the order of the channels and uses geoprocessing techniques to extract the basin drainage network, which was characterized as 4th order. In addition, 24 channels were characterized 1st order, 7 channels as 2 nd order, and 2 channels as 3rd order (Figure 3(a))

The watershed area of the Indaiá stream has a total length of $64.0938 \mathrm{~km}$, including all of its channels, and the main channel is $17.9875 \mathrm{~km}$ (Table 2). Extensive channels are present throughout the basin. According to reference [38], the length of the channel is directly related to the topography; channels that are longer develop in smoother gradients, a fact that was evident in the study area, where the terrain features undulating soft forms 
Table 1. Description of morphometric parameters (linear and areal relief).

\begin{tabular}{|c|c|c|c|}
\hline Parameters & Formula & Description & References \\
\hline \multicolumn{4}{|c|}{ Linear parameter } \\
\hline $\begin{array}{l}\text { Hierarchical order } \\
\text { (Strahler classification) }\end{array}$ & Fluvial hierarchy & $\begin{array}{l}\text { Establishing the classification of a given body of water and the } \\
\text { whole set of the watershed in which it is located. }\end{array}$ & {$[2]$} \\
\hline $\begin{array}{l}\text { Lr-Length of } \\
\text { the main river }\end{array}$ & $\begin{array}{l}\text { Higher-order } \\
\text { channel }\end{array}$ & & {$[1]$} \\
\hline $\begin{array}{l}\text { Lt-Total length of all } \\
\text { channels }(\mathrm{km})\end{array}$ & $\begin{array}{l}\text { Sum of all channels } \\
\text { of the basin }\end{array}$ & & [1] \\
\hline \multicolumn{4}{|c|}{ Areal parameter } \\
\hline A-Drainage area $\left(\mathrm{km}^{2}\right)$ & & Entire area drained by the set river system. & {$[7]$} \\
\hline P-Perimeter (km) & & Measure the two-dimensional contour of the basin & [7] \\
\hline L-Basin length (km) & & $\begin{array}{l}\text { Distance measured in a straight line between the mouth and the } \\
\text { highest point located along the perimeter. }\end{array}$ & [7] \\
\hline $\begin{array}{l}\text { Kc-Coefficient of } \\
\text { compactness }\end{array}$ & $K c=0.28 \frac{P}{\sqrt{A}}$ & $\begin{array}{l}\text { The compactness coefficient }(\mathrm{Kc}) \text { associated with the basin form is a } \\
\text { circle, and the relationship between the perimeter of the basin and } \\
\text { the circumference of a circle of area is equal to that of the basin. }\end{array}$ & {$[1]$} \\
\hline F-Basin form & $F=\frac{A}{L^{2}}$ & $\begin{array}{l}\text { Relating to the form shape of a rectangle, corresponding to the ratio } \\
\text { between the average length and the axial length of the form. }\end{array}$ & {$[7]$} \\
\hline $\begin{array}{l}\text { Dd-Drainage density } \\
\quad\left(\mathrm{km} \cdot \mathrm{km}^{-2}\right)\end{array}$ & $D d=\frac{L_{t}}{A}$ & $\begin{array}{l}\text { The density of the drainage correlates the length of the flow channels } \\
\text { with the watershed area. }\end{array}$ & {$[1]$} \\
\hline $\begin{array}{l}\text { Cm-Maintaining } \\
\text { Coefficient }\end{array}$ & $C m=\frac{1}{D d} \cdot 1000$ & $\begin{array}{l}\text { This index is intended to provide the minimum area necessary for the } \\
\text { maintenance of the one-meter flow channel. }\end{array}$ & {$[5]$} \\
\hline \multicolumn{4}{|c|}{ Relief parameter } \\
\hline $\begin{array}{c}\text { Altimetry } \\
\text { amplitude (m) }\end{array}$ & & $\begin{array}{l}\text { Corresponds to the altimetric difference between the } \\
\text { highest and lowest points along the basin. }\end{array}$ & [5] \\
\hline $\begin{array}{l}\text { Interfluvial dimension } \\
\text { (Horizontal dissection) }\end{array}$ & & Distance between channels. & {$[50]$} \\
\hline $\begin{array}{l}\text { Amplitude altimetry } \\
\text { (Vertical dissection) }\end{array}$ & & Drainage deepening of intensity. & {$[60]$} \\
\hline \multicolumn{4}{|l|}{ Altitude } \\
\hline Slope & & $\begin{array}{l}\text { The slope is the angle of inclination of the local surface } \\
\text { relative to the horizontal plane. }\end{array}$ & [51] \\
\hline Aspect & & The slope variation of direction & {$[51]$} \\
\hline
\end{tabular}

that are characterized by the predominance of convex hills with an average slope of 5.50\%.

The drainage density factor is directly related to climate, lithology of the rocks, relief, infiltration capacity and vegetation cover [7] [16]. The study area is in the category of low drainage density $\left(0.6769 \mathrm{~km} / \mathrm{km}^{2}\right)$, suggesting that the basin has good permeability. This behavior is associated with the infiltration process, which is favored by the lithological constitution of the Furnas and Aquidauana formations, which in turn essentially comprise coarse-grained sandstones.

The compactness coefficient of the basin is 1.4112. When the coefficient unit (1) corresponds to a circular shape (representing a tendency to flood), the form factor $(0.4538)$ is considered low. From the combined analysis of the values found, it is possible that the basin has a low susceptibility to flooding; however, a more elongated pattern facilitates the runoff of rain water, thereby favoring the development of erosion.

According to reference [5], the maintenance coefficient is one of the most important numerical values for characterizing the drainage system and is intended to provide the minimum area for the maintenance of a flow channel tube [7]. The value obtained is $1477.32 \mathrm{~km}^{2} / \mathrm{km}$. Evidently, the basin is low in water course. 
Table 2. Indaiá stream watershed parameters assessed.

\begin{tabular}{|c|c|}
\hline Parameters & \multirow{2}{*}{ Total } \\
\hline Parameter linear & \\
\hline Fluvial hierarchical order (Strahler classification) & $4^{\mathrm{a}}$ \\
\hline Lr-Length of the main river & 17.9875 \\
\hline Lt-Total length of all channels (km) & 64.0938 \\
\hline \multicolumn{2}{|l|}{ Parameter areal } \\
\hline A-Drainage area $\left(\mathrm{km}^{2}\right)$ & 94.6764 \\
\hline P-Perimeter $(\mathrm{km})$ & 49.0430 \\
\hline L-Basin length $(\mathrm{km})$ & 14.4440 \\
\hline Dd-Drainage density $\left(\mathrm{km} \cdot \mathrm{km}^{-2}\right)$ & 0.6769 \\
\hline Kc-Coefficient of compactness & 1.4112 \\
\hline F-Basin form & 0.4538 \\
\hline Cm-Maintaining Coefficient $\left(\mathrm{km}^{2} / \mathrm{km}\right)$ & 1477.3230 \\
\hline \multicolumn{2}{|l|}{ Relief Parameter } \\
\hline Altimetry amplitude & 387 \\
\hline Interfluvial dimension mean (m) & 454 \\
\hline Altitude mean (m) & 275 \\
\hline Slope mean (\%) & 5.50 \\
\hline Aspect (predominant direction) & North/East \\
\hline
\end{tabular}

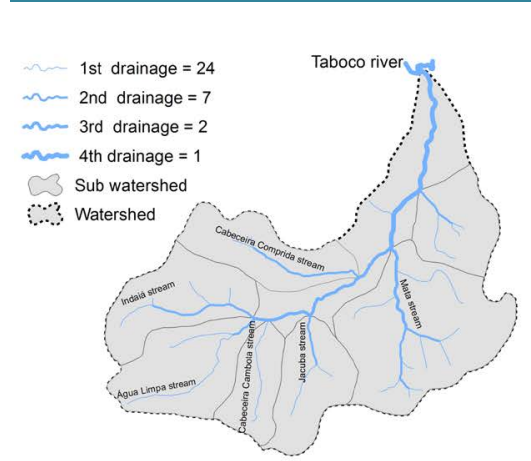

(a)

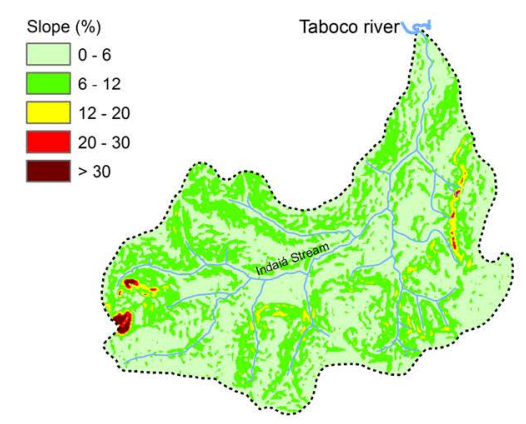

(c)

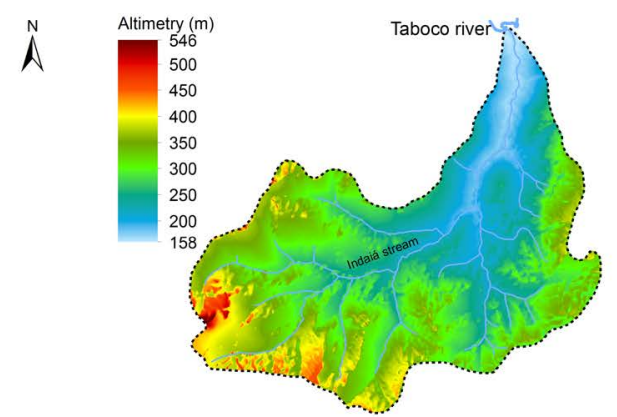

(b)

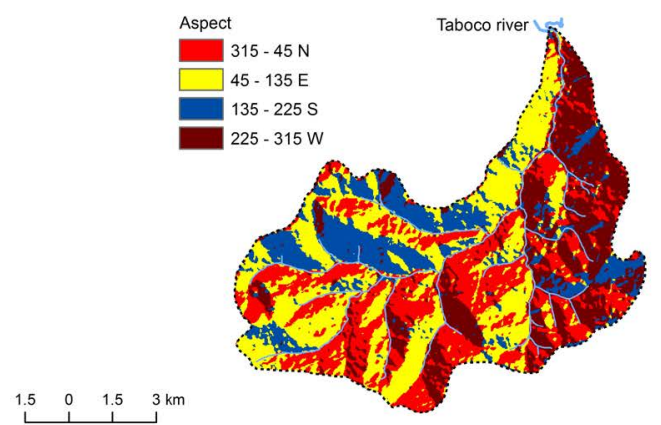

(d)

Figure 3. (a) Watershed limit, sub-basins and channel order, (b) altitude, (c) slope and (d) aspect.

The hypsometry was divided into 8 classes, ranging from an altitude of $546 \mathrm{~m}$ to $158 \mathrm{~m}$ (Figure 3(b)), setting an altimetry range of $387 \mathrm{~m}$ (Table 2). The altimetric amplitude from the mouth of the Taboco River to more 
than half of its middle course is very low (approximately $100 \mathrm{~m}$ ). To the west is the highest altitude (546 m), which is associated with strongly undulation and has slopes exceeding $30 \%$. In the east, towards the mouth of the Taboco River, the altimetric levels reach approximately 156 meters, where the relief ranges from plane (fluvial plain) to soft wavy (convex hills) that have slopes reaching $<20 \%$. The arrangement of the higher elevations to the west and lower east evidences the direction of flow of the drainage (O-L).

The mapping of the slope (Figure 3(c)) is an important analysis feature of a watershed. According to reference [57], the slope relates to the speed of the runoff, thereby affecting the time required for rain water to concentrate in the river beds that make up the network of the drainage basin. The flood peaks, infiltration and susceptibility to soil erosion depend on the speed with which the flow occurs on the ground of the basin.

In this sense, it is essential to understand the distribution of the relief slope because it provides information for the planning and mechanization of agriculture, the planning of engineering structures, and conservation practices [36] [37].

We identified that $61 \%$ of the basin dominates the lower slopes, with between $0 \%$ - $6 \%$ of the basin being associated with reliefs and exhibiting practically plane and soft wavy shapes; this area is located between the sources of its tributaries and the mouth of the Taboco River. The slopes steeper than $30 \%$ comprise $0.4 \%$ of the basin and occur in the west, in areas where the relief has strong waveforms that are characterized by the presence of hillocks and hills.

According to reference [58], the hillside "is the dominant element of relief in most regions, presenting itself as the most important form of relief for man, both for agriculture, as the other buildings work."

The mapping of the aspect (Figure 3(d)) of the Indaiá stream watershed presents a complexity in disposition that justifies the various flows into the basin; however, the aspects oriented to the north $(\mathrm{N})$ and east (L) stand out.

To reference [59], the surfaces next to the Tropic of Capricorn tend to have aspects oriented north that are hotter and with drought compared with those in the south. In this sense, reference [60] stresses that any radiation flux that reaches a rather steep aspect positioned to the north in southern subtropical areas will be more intense than other aspects that have the same slope and location but are positioned to the south, a fact that favors the largest weathering of these aspects.

According to reference [60], the relief dissection of the drainage intensity is directly related to porosity, permeability and rock. The area watershed of the Indaiá stream is structured on the Furnas and Aquidauana Formations, which are composed of porous and friable sandstones [45]. This lithological characteristic favors the infiltration of rain water; consequently, the amount of water surface is lower, resulting in a number fewer channels and increasing distances between interfluves (Figure 4(a)).

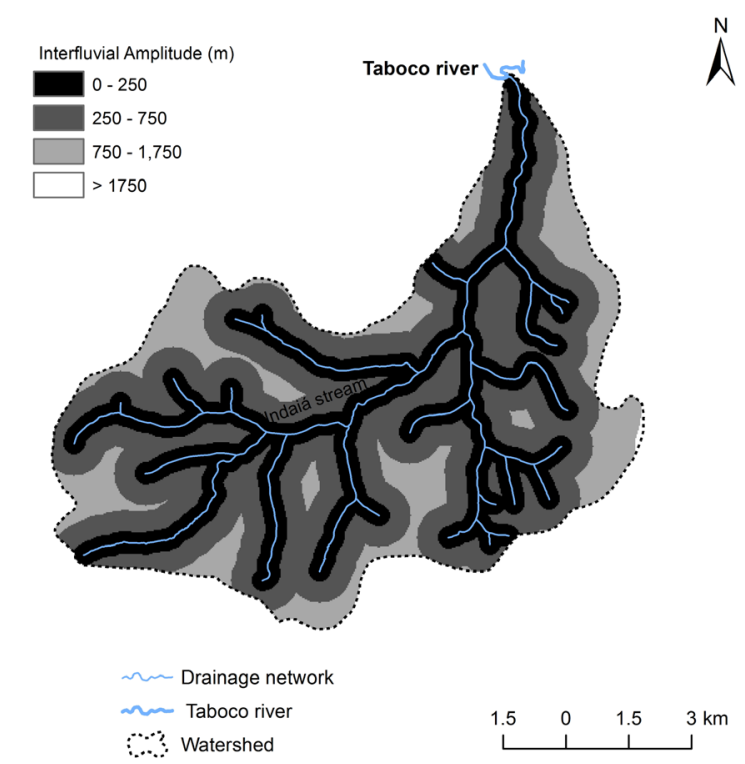

(a)

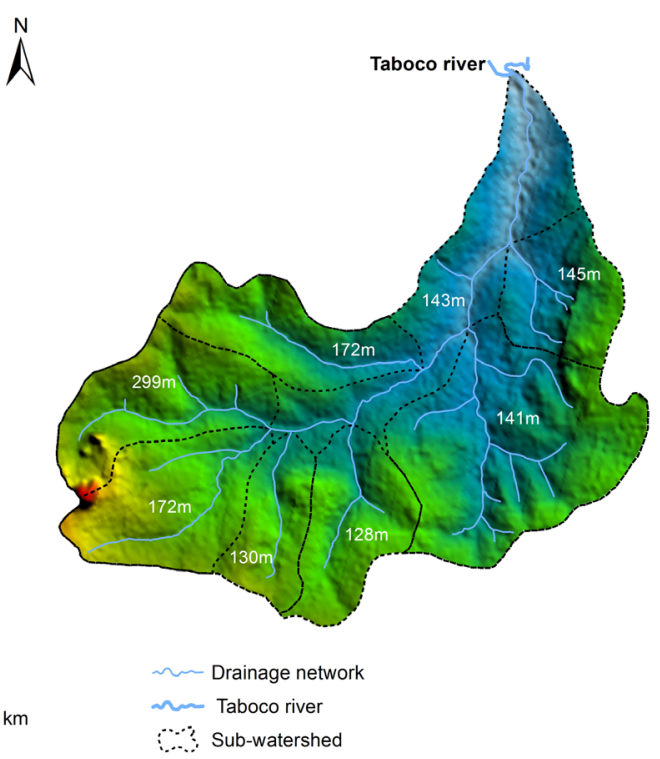

(b)

Figure 4. (a) Interfluvial amplitude (horizontal dissection), (b) vertical amplitude (vertical dissection). 
By analyzing the horizontal and vertical dissection (Figure 4(a) \& Figure 4(b)), we identified the predominance of channels at intervals of 250 - $750 \mathrm{~m}$ (average interfluvial size of $454 \mathrm{~m}$ ). The notching of the very strong valleys (average $166 \mathrm{~m}$ ) features a dissected relief that is dominated by hills with convex, U-shaped valleys.

\section{Conclusions}

The interferometric SRTM radar data showed satisfactory results in the morphometric characterization. This survey highlights the potential of radar metric products in the analysis of relief morphometry to serve as a basis for geomorphological mapping. Combined with other data (e.g., soil, use, vegetation cover, climate), such products can support diagnostics and environmental and land use analyses.

From the integrated analysis of morphometric variables, we conclude that the watershed has low susceptibility to flooding. However, the geological structure, which consists predominantly of sandstones and is marked by the presence of quartz associated with the hilly relief, favors the development of erosion by water.

The result of the morphometric characterization shows important variables, particularly in relation to the horizontal and vertical dissection cards that can assist in the planning, use and management of resources in a watershed that supports a rural settlement complex.

\section{Acknowledgements}

This work was supported by the Federal University Foundation of Mato Grosso do Sul (PROPP/UFMS). We thank the financial support provided by FUNDECT (PAPOS/2014).

\section{References}

[1] Horton, R.E. (1945) Erosional Development of Streams and Their Drainage Basins; Hydrophysical Approach to Quantitative Morphology. Geological Society of America Bulletin, 56, 275-370. http://dx.doi.org/10.1130/0016-7606(1945)56[275:EDOSAT]2.0.CO;2

[2] Strahler, A.N. (1954) Quantitative Geomorphology of Drainage Basins and Channel Networks. In: Chow, V.T., Ed., Handbook of Applied Hydrology, McGraw Hill, New York, 4, 39 and 76.

[3] Strahler, A.N (1957) Quantitative Analysis of American Geomorphology. Transaction American Geophysical Union, 38, 913-920. http://dx.doi.org/10.1029/TR038i006p00913

[4] Strahler, A.N (1958) Dimensional Analysis Applied to Fluvial Eroded Landforms. Geological Society of America Bulletin, 69, 279-300. http://dx.doi.org/10.1130/0016-7606(1958)69[279:DAATFE]2.0.CO;2

[5] Schumm, S.A. (1956) Evolution of Drainage Systems and Slopes in Badlands of Perth Amboy, pp. 597-646. Geological Society of America Bulletin, 67.

[6] Christofoletti, A. (1970) Análise morfométrica das bacias hidrográficas do Planalto de Poços de Caldas (MG) Tese de Livre Docência. Instituto de Geociências e Ciências Exatas, Universidade Estadual Paulista, Rio Claro.

[7] Christofoletti, A. (1999) Modelagem de Sistemas Ambientais. Edgard Blücher, São Paulo.

[8] Feltran Filho, A. (1982) Contribuição à análise fluviométrica da bacia do rio Piracicaba. 188 p. Dissertação. Universidade Estadual Paulista, Instituto de Geociências e Ciências Exatas, Rio Claro.

[9] Maio, C.R (1990) Parâmetros geomorfológicos na identificação de áreas homogêneas. Cadernos de Geociências, No. 5, 21-52.

[10] Nag, S.K. (1998) Morphometric Analysis Using Remote Sensing Techniques in the Chaka Sub Basins, Purulia District, West Bengal. Journal of Indian Society of Remote Sensing, 26, 69-76. http://dx.doi.org/10.1007/BF03007341

[11] Walcott, R.C. and Summerfield, M.A. (2007) Scale Dependence of Hypsometric Integrals: An Analysis of Southeast African Basins. Geomorphology, 96, 174-186.

[12] Thomas, J., Joseph, S. and Thrivikramaji, K.P. (2010) Morphometric Aspects of Small Tropical Mountain River System, the Southern Western Ghats, India. International Journal of Digital Earth, 3, 135-156. http://dx.doi.org/10.1080/17538940903464370

[13] Mishra, S.S. and Nagrajan, R. (2010) Morphometric Analysis and Prioritization of Sub-Watershed a Using GIS and Remote Sensing Techniques: A Study of OdiSha, India. International Journal of Geomatics and Geosciences, 1, 501510.

[14] Langbein, W.B. (1947) Topographic Characteristics of Drainage Basins. US Geological Survey Water-Supply Paper, 968-C, 125-157.

[15] Chorley, R.J., Schumm, S.A and Sugden, D.E. (1984) Geomorphology. Methuen, London. 
[16] Vittala, S.S., Govindaiah, S. and Gowda, H.H (2004) Morphometric Analysis of the Sub-Watersheds in the Pavagada Area of Tumkur District, South India Using Remote Sensing and GIS Techniques. Journal of the Indian Society of Remote Sensing, 32, 351-361. http://dx.doi.org/10.1007/BF03030860

[17] Vijith, H. and Satheesh, R. (2006) Based Morphometric Analysis of two Major Upland Subwatersheds of Meenachil River in Kerala. Journal of the Indian Society of Remote Sensing, 34, 181-185. http://dx.doi.org/10.1007/BF02991823

[18] Rudraiah, M., Govindaiah, S. and Vittala, S. (2008) Morphometry Using Remote Sensing and GIS Techniques in the Sub-Basins of Kagna Basin, Gulburga District, Karnataka, India. Journal of the Indian Society of Remote Sensing, 36, 351-360. http://dx.doi.org/10.1007/s12524-008-0035-x

[19] Al Saud, M. (2009) Morphometric Analysis of Wadi Aurnah Drainage System, Western Arabian Peninsula. Open Hydrology Journal, 3, 1-10.

[20] Rao, N.K., Latha, S.P., Kumar, A.P. and Krishna, H.M. (2010) Morphometric Analysis of Gostani River Basin in Andhra Pradesh State, India Using Spatial Information Technology. International Journal of Geomatics and Geosciences, 1, 179-187.

[21] Rao, L.A., Rehman, A. and Yusuf, A. (2011) Morphometric Analysis of Drainage Basin Using Remote Sensing and GIS Techniques: A Case Study of Etmadpur Tehsil, Agra District, U.P. International Journal of Research in Chemistry and Environment, 1, 36-45.

[22] Zende, A. and Nagrajan, R. (2011) Drainage Morphology Approach for Water Resources Development of Sub Watershed in Krishna Basin. International Journal of Computer \& Communication Technology, 2, 13-21.

[23] Mishra, A., Dubey, D. and Tiwari, R. (2011) Morphometric Analysis of Tons Basin, Rewa District, Madhya Pradesh, Based on Watershed Approach. Earth Science India, 4, 171-180.

[24] Pal, S.C. and Debnath, G.C. (2012) Morphometric Analysis and Associated Land Use Study of a Part of the Dwarkeswar Watershed. International Journal of Geomatics and Geosciences, 3, 351-363.

[25] Shikalgar, R.S. (2013) Morphometric Analysis and Prioritization of Watershed for Soil Resource Management in Yerala River Basin. India Streams Research Journal, 3, 1-5.

[26] Markose, V.J., Dinesh, A.C. and Jayappa, K.S. (2014) Quantitative Analysis of Morphometric Parameters of Kali River Basin, Southern India, Using Bearing Azimuth and Drainage (bAd) Calculator and GIS. Environmental Earth Sciences, 72, 2887-2903. http://dx.doi.org/10.1007/s12665-014-3193-x

[27] Patel, D.P., Gajjar, C.A. and Srivastava, P.K. (2013) Prioritization of Malesari Mini-Watersheds through Morphometric Analysis: A Remote Sensing and GIS Perspective. Environmental Earth Sciences, 69, 2643-2656. http://dx.doi.org/10.1007/s12665-012-2086-0

[28] Vieceli N., Bortolin, T.A., Mendes, L.A., Bacarim, G., Cemin, G. and Schneider, V.E. (2015) Morphometric Evaluation of Watersheds in Caxias do Sul City, Brazil, Using SRTM (DEM) Data and GIS. Environmental Earth Sciences, 73, 5677-5685. http://dx.doi.org/10.1007/s12665-014-3823-3

[29] Valeriano, M.M. (2004) Modelo digital de elevação com dados SRTM disponíveis para a América do Sul. INPE, São José dos Campos, 72 p.

[30] Valeriano, M.M. (2005) Modelagem Digital do Terreno com Dados SRTM. INPE, São José dos Campos. Apostila.

[31] Sarangi, A., Madramootoo, C. and Enright, A. (2003) Development of User Interface in ArcGIS for Estimation of Watershed Geomorphology. CSAE/SCGR Meeting, Montreal, 6-9 July 2003, Paper No. 03-120.

[32] Obi Reddy, G.P., Maji, A.K. and Gajbhiye, K.S. (2004) Drainage Morphometry and Its Influence on Landform Characteristics in a Basaltic Terrain, Central India-A Remote Sensing and GIS Approach. International Journal of Applied Earth Observation and Geoinformation, 6, 1-16. http://dx.doi.org/10.1016/j.jag.2004.06.003

[33] Valeriano, M.M., Kuplich, T.M., Storino, M., Amaral, B.D., Mendes Jr., J.N. and Lima, D.J. (2006) Modeling Small Watershed in Brazilian Amazonia with Shuttle Radar Topographic Mission-90m Data. Computers \& Geosciences, 32, 1169-1181. http://dx.doi.org/10.1016/j.cageo.2005.10.019

[34] Grohmann, C.H., Riccomini, C. and Alves, F.M. (2007) SRTM-Based Morphotectonic Analysis of the Poços de Caldas alkaline Massif, Southeastern Brazil. Computers \& Geosciences, 33, 10-19. http://dx.doi.org/10.1016/j.cageo.2006.05.002

[35] Ozdemir, H. and Bird, D. (2009) Evaluation of Morphometric Parameters of Drainage Networks Derived from Topographic Maps and DEM in Point of Floods. Environmental Geology, 56, 1405-1415. http://dx.doi.org/10.1007/s00254-008-1235-y

[36] Sreedevi, P.D., Subrahmanyam, K. and Shakeel, A. (2005) The Significance of Morphometric Analysis for Obtaining Ground Water Potential Zones in a Structurally Controlled Terrain. Environmental Geology, 47, 412-420. http://dx.doi.org/10.1007/s00254-004-1166-1

[37] Sreedevi, P.D., Owais, S., Khan, H.H. and Ahmed, S. (2009) Morphometric Analysis of a Watershed of South India 
Using SRTM Data and GIS. Journal of the Geological Society of India, 73, 543-552. http://dx.doi.org/10.1007/s12594-009-0038-4

[38] Sreedevi, P.D., Sreekanth, P.D., Khan, H.H. and Ahmed, S. (2013) Drainage Morphometry and Its Influence on Hydrology in a Semi Arid Region: Using SRTM Data and GIS. Environmental Earth Sciences, 70, 839-848. http://dx.doi.org/10.1007/s12665-012-2172-3

[39] Kanth, T.A. and Hassan, Z. (2012) Morphometric Analysis and Prioritization of Watersheds for Soil and Water Resource Management in Wular Catchment Using Geo-Spatial Tools. International Journal of Geology, Earth and Environmental Sciences, 2, 30-41.

[40] Oliveira, P.T.S., Sobrinho, T.A., Steffen, J.L. and Rodrigues, D.B.B. (2010) Caracterização morfométrica de bacias hidrográficas através de dados SRTM. Revista Brasileira de Engenharia Agrícola e Ambiental, 14, 819-825. http://dx.doi.org/10.1590/S1415-43662010000800005

[41] Rao Tamma, G., Rao Gurunadha, S.V.V.S., Ratnakar, D., Rao Mallikharjuna, S.T. and Rao Raja, B.M. (2012) Remote Sensing and GIS Based Comparative Morphometric Study of Two Sub-Watershed of Different Physiographic Conditions, West Godavari District, A.P. Journal Geological Society of India, 79, 383-390. http://dx.doi.org/10.1007/s12594-012-0059-2

[42] Ansari, Z.R., Rao, L.A.K. and Yusuf, A. (2012) GIS Based Morphometric Analysis of Yamuna Drainage Network in Parts of Fatehabad Area of Agra District, Uttar Pradesh. Journal of the Geological Society of India, 79, 505-514. http://dx.doi.org/10.1007/s12594-012-0075-2

[43] Prabu, P. and Baskaran, R. (2013) Drainage Morphometry of Upper Vaigai River Sub-Basin, Western Ghats, South India Using Remote Sensing and GIS. Journal of the Geological Society of India, 82, 519-529. http://dx.doi.org/10.1007/s12594-013-0183-7

[44] Kaliraj, S., Chandrasekar, N. and Magesh, N.S. (2015) Morphometric Analysis of the River Thamirabarani Sub-Basin in Kanyakumari District, South West Coast of Tamil Nadu, India, Using Remote Sensing and GIS. Environmental Earth Sciences, 73, 7375-7401.

[45] Brasil, Ministério das Minas e Energias. Secretaria Geral (1982) Projeto RADAMBRASIL: Geologia, Geomorfologia, Pedologia, Vegetação e Uso potencial da terra. Rio de Janeiro, Folha SE. 21. Campo Grande.

[46] Maack, R. (1950) Vestígios pré-devonianos de glaciação e a sequencia de camadas devonianas no Estado do Paraná. Arquivos de Biologia e Tecnologia, 5/6, 197-230.

[47] Beurlen, K. (1956) A geologia pós-algonquiana do sul do Estado de Mato Grosso. Boletim da Divisão de Geologia e Mineralogia, No. 163, 1-137.

[48] Gonçalves, A. and Schneider, R.L. (1970) Geologia do centro-leste de Mato Grosso. PETROBRÁS-DESUL, Ponta Grossa, 43 p (Relatório Técnico Interno, 394).

[49] Cunha, E.R., Bacani, V.M. and Ayach, L.R. (2013) Geoprocessamento aplicado à análise da fragilidade ambiental. Revista da ANPEGE, 9, 89-105.

[50] Ross, J.L.S. (1992) O registro cartográfico dos fatos geomórficos e a questão da taxonomia do relevo. Revista do Departamento de Geografia, 6, 17-30.

[51] Ross, J.L.S. (1994) Análise Empírica da Fragilidade dos Ambientes Naturais e Antropizados. Revista do Departamento de Geografia, 8, 63-74.

[52] Cardoso, C.A., Dias, H.C.T., Soares, C.P.B. and Martins, S.V. (2006) Morphometric characterization of Debossan river watershed, Nova Firburgo, RJ. Revista Árvore, 30, 241-248.

[53] Fitz, P.R. (2008) Cartografia Básica. Oficina de Textos, São Paulo.

[54] Valeriano, M.M. (2008) TOPODATA: Guia de utilização de dados geomorfométricos locais. INPE, São José dos Campos.

[55] Câmara, G., Monteiro, A.M.V. and Medeiros, J.S. (2003) Fundamentos epistemológicos da ciência da geoinformação. Geografia Rio Claro, 28, 83-96.

[56] Casseti, V. (2005) Geomorfologia. http://www.funape.org.br/geomorfologia/

[57] Villela, S.M. and Mattos, A. (1975) Hidrologia aplicada. McGraw-Hill do Brasil, São Paulo, 245 p.

[58] Tricart, J. (1957) Mise em point: L’évolution des versants. L'information Geographique, 21, 108-116. http://dx.doi.org/10.3406/ingeo.1957.1708

[59] Lepsh, I.F. (2002) Formação e conservação dos Solos. Oficina de Texto, São Paulo.

[60] Crepani, E., Medeiros, J.S., Hernandez Filho, P., Florenzano, T.G., Duarte, V. and Barbosa, C.C.F. (2001) Sensoriamento remoto e geoprocessamento aplicados ao Zoneamento Ecológico-Econômico e ao ordenamento territorial. (INPE8454-RPQ/722). Instituto Nacional de Pesquisas Espaciais, São José dos Campos. 